\title{
The Ontology of Epistemic Reasons
}

\author{
Forthcoming in Noûs \\ John Turri \\ Huron University College \\ john.turri@gmail.com
}

\begin{abstract}
Epistemic reasons are mental states. They are not propositions or non-mental facts. The discussion proceeds as follows. Section 1 introduces the topic. Section 2 gives two concrete examples of how our topic directly affects the internalism/externalism debate in normative epistemology. Section 3 responds to an argument against the view that reasons are mental states. Section 4 presents two problems for the view that reasons are propositions. Section 5 presents two problems for the view that reasons are non-mental facts. Section 6 argues that reasons are mental states. Section 7 responds to objections.
\end{abstract}

\section{Introduction}

Here's an uncontroversial starting point: we believe things for reasons all the time. Not even skeptics need disagree, for they would be vindicated if it turned out that all our beliefs were based on bad 
reasons. Of course most of us will disagree with the skeptic on this latter point. But I first want to get clearer on our common point of agreement. Just what kind of thing are reasons to begin with?

Let's reserve the term 'epistemic reason' for those reasons upon which our beliefs are based. Sometimes I speak of "reasons for believing," intending exactly same meaning. What I call the basis of belief, some authors call the "grounds" of belief (Alston 1985, Pryor 2005).

Confusion abounds in epistemology on our question. Consider this passage from Richard Feldman:

[A] chain of reasons or an evidential chain ... is a structured sequence of beliefs, each of which is justified by its predecessors. It is important to notice that an evidential chain need not have just one proposition at each link or level. For example, in tracing out the evidential chain associated with Careful's belief [that Filcher stole the painting], we might have the facts about the fingerprints and the possession of the paintings as the reasons for [Careful's belief]. There will be further reasons for each of these, perhaps involving the results of the fingerprint tests and the like. (Feldman 2003: 50, bold emphasis added) ${ }^{1}$

Within the span of a paragraph we are told that reasons are beliefs, propositions, and facts. Consider also these typical passages from

1 The surrounding context suggests that Feldman thinks reasons are beliefs, not propositions or facts. 
Peter Klein, valiant proponent of infinitism:

Infinitism is like foundationalism in holding that there are features of the world ... that make a belief a reason . . . Infinitism is unlike foundationalism because infinitism holds that there are no ultimate, foundational reasons .... [T] he chain of reasons cannot end with an arbitrary reason-one for which there is no further reason . . . arbitrary beliefs, beliefs for which no reason is available, should be avoided. (Klein 1999: 298 - 299, bold emphasis added)

There is an infinite chain of propositions ... for every proposition. But only some chains contain reasons. Hence, not every proposition will have a justification because a proposition has a justification only if each member of the chain is available as a reason .... (Klein 1999: 312, bold emphasis added)

Finally consider these passages from James Pryor:

We introduced the notion of a ground to distinguish between cases where you believe $\mathrm{P}$ for good reasons, or on grounds that justify you in believing $\mathrm{P}$, and cases where you believe $\mathrm{P}$ on bad grounds, ones that do not justify that belief. What does it take for your belief to be grounded on some fact or condition $\mathbf{C}$ that you are in? (Pryor 2005: 195, bold emphasis added)

Say that some grounds E you have 'allow' a possibility 
$q$ iff the following counterfactual is true: if $q$ obtained, you would still possess the same grounds E. Many skeptical scenarios are incompatible with what we purport to know on the basis of our experiences, but are "allowed" by those experiences, in this sense. For instance, your experiences at the zoo seem to justify you in believing that there is a zebra in the pen. This belief is incompatible with the hypothesis that the animal in the pen is a mule painted to look like a zebra. But that is a hypothesis which is "allowed" by your experiences. If it were a painted mule in the pen, you would most likely be having the same experiences, and hence, the same grounds for believing that there is a zebra in the pen. (Pryor 2000: 527, bold emphasis added)

So what are epistemic reasons-are they mental states, such as experiences or beliefs? Propositions? Facts? Something else entirely?

Ethicists and action theorists study an analogous question. ${ }^{2} \mathrm{We}$ act for reasons all the time too, but what kind of thing are practical reasons? The metaphysical territory here is better explored, so I will use their taxonomy to guide our inquiry into epistemic reasons. The main options are:

Psychologism: All reasons are psychological items. ${ }^{3}$

2 Alvarez 2005 reviews some recent work.

3 I believe Jonathan Dancy introduced the terms 'psychologism' and 'anti-psychologism' into the literature. 
Anti-psychologism: No reason is a psychological item.

Dualism: Some but not all reasons are psychological items. $^{4}$

Psychological items include mental states, events, processes and mental facts about the subject. We'll focus on one specific version of psychologism and two versions of anti-psychologism. I defend this version of psychologism:

Statism: Reasons are the subject's mental states or events. ${ }^{5}$

I critique these versions of anti-psychologism:

Abstractionism: Reasons are the propositional con-

4 Stoutland (1998: 61) appears to advocate this view.

5 Statists include Davidson (1983: 141), Swain (1981: Chapter 3), Pollock (1986: Chapter 5), Neta (2002: 669), and Bergmann (2007). Sometimes McDowell (1979: Section 5; 1994: 10) says things that put him squarely in the statist camp, but other times (e.g. 1994: 36, 39) he sounds like a factualist-reasons are "facts," "features of the world," or "states of affairs." He informs me that he favors factualism. Statism does not rule out McDowell's (1994: Lecture II) view of empirical content, according to which the content of a perceptual state or a true perceptual judgment is literally some external, non-mental fact. Combining statism with McDowell's view of empirical contentor with Clark and Chalmers's (1998) extended mind hypothesis-we would say that reasons are psychological items, (at least) some of which literally contain non-psychological items. Some might view this combination as a satisfying way to split the difference between psychologism and anti-psychologism. A potentially attractive version of statism, which I do not consider here in detail, says that reasons are (token) properties of mental states; this might be Ernest Sosa's view. 
tents of the subject's mental states. ${ }^{6}$

Factualism: Reasons are non-mental facts or states of affairs. ${ }^{7}$

I won't explicitly critique dualism, which finds relatively few explicit advocates in the literature. But my positive argument in section 6 works equally well against dualism.

Let me clarify what these are not theories of. They are not theories of reasons that there are to believe Q, which differ importantly from epistemic reasons in the sense we are dealing with, for at least two reasons. ${ }^{8}$ First, reasons that there are to believe Q need not be had. There might be reasons none of us has to believe that an influenza pandemic will occur. But to believe on the basis of a reason, you must have it. Second, reasons that there are to believe $\mathrm{Q}$ are always good reasons to believe Q. ${ }^{9}$ But you can believe Q on the basis

6 Abstractionists include Darwall (1983: 31 - 32), Scanlon (1999: 56 57), and Brandom (2000: 18).

7 Factualists include Dancy (2000), Collins (1997), and McDowell (1994). The view as stated needs qualification. Factualists will agree that our introspective beliefs are based on mental facts or states, but they deem these uninteresting special cases, and insist that this qualification does not spoil the spirit of their view. I think this presents more of a problem than factualists want to admit, perhaps indicating that many factualists are ultimately dualists. But I won't explore the matter here.

8 In terminology familiar from the literature on practical reasons, I understand the competitors as theories of motivating reasons. I revisit the distinction between motivating and normative reasons below in section 3.

9 See, e.g., Darwall 1983: 30 - 31, Scanlon 1998: 18 - 19, and Dancy 2000: Chapter 1. One might say, "There are plenty of reasons to believe the moon is made of cheese-and they're all bad!" But to my ear, taken literally this sounds like a retraction. I'd cooperatively un- 
of bad reasons.

The competitors are likewise not theories of the reasons why you believe Q. More precisely, none is a general theory of the reasons why. Epistemic reasons form a proper subset of the reasons why you believe. 'Why does he think that?' is potentially ambiguous in a way that 'What's his reason for thinking that?' isn't. Explanations abound for why we believe what we do, not all of which reveal our reasons. Consider my victimized twin, ensnared and deceived by a powerful evil genius. My twin believes that he is sitting in his office. Why does he believe that? One correct answer: because the evil genius deceives him. This helps explain his belief, but surely it's not his reason for thinking he's in his office! Mistaking that for his reason leads to the false conclusion that my twin is startlingly irrational.

Another possible view, which I do not here evaluate, is contextualism about reasons (or reason ascriptions). This view states that the truth conditions for expressions of the form ' $S$ 's belief that $Q$ is based on R' or ' $\mathrm{R}$ is S's reason for believing Q' vary with features of the speaker's context. In ordinary contexts you could truthfully say 'Moore's belief that he has hands is based on the fact that he has hands'. But to speak truthfully in contexts where the possibility of perceptual hallucination or systematic deception has been raised,

derstand it as an ironic or humorous way of saying that there is no reason to believe the moon is made of cheese. At the very least, there is a perfectly respectable sense in which something isn't a reason at all to believe $Q$ if it isn't a good reason to believe $Q$. It is this sense I intend. 
you would instead have to say 'Moore's belief is based on his experience as of two hands'. ${ }^{10}$ You might endorse this view because, on the one hand, reasons are explanatory and, on the other, explanation is context-sensitive. It would thus be unsurprising if reasons-talk was context-sensitive. You could then deploy reasons-contextualism to help solve stubborn skeptical puzzles, just as familiar contextualist theories in normative epistemology have been. Reasons-contextualism holds at least one advantage over standard contextualist theories. Whereas the latter typically invoke controversial theses about the semantics of 'knows' to explain the purported context-sensitivity of knowledge ascriptions, the former need invoke only the comparatively uncontroversial thesis that explanation is context-sensitive (compare Rieber 1998: 194ff and Greco 2003b). ${ }^{11}$

At least four observations ought to constrain our theory of reasons. First, reasons are explanatory. To say this is not to confuse epistemic reasons with merely causal reasons. When you believe $\mathrm{Q}$ for a reason, you believe because of that reason-the reason explains your belief. An adequate theory must respect this. Second, ideally a theory should respect the following intuition. Your victimized twin, Vic, recently ensnared by an evil genius, undergoes an indefinite succession of experiences indistinguishable from yours. Responding to the very same kinds of sensory experiences as you, Vic believes

${ }^{10}$ Ram Neta (2003: esp. 21 - 26) says some things that, suitably modified (he talks of "evidence" rather than "reasons"), might suggest a view along these lines.

${ }^{11}$ For standard contextualist theories, see Lewis 1996, DeRose 1999, and Cohen 1998, 2005. 
that he or she is reading an epistemology paper. Intuitively you and your twin believe what you do for the same reasons (compare Berkeley 1710: §20, Nozick 1981: 184 - 185, Foley 1990: 184, BonJour 2003: 185 - 186, Sosa 2003: 150, and Huemer 2007: 48). Third, a theory of reasons should generalize beyond belief and apply equally well to disbelief and withholding. Fourth, a theory of reasons should not make our job in constructing an adequate normative epistemology too difficult-for instance, when explaining the reasonableness of perceptual beliefs.

As already suggested, I assume that it is possible to believe based on a bad reason. I am more than comfortable letting my argument ultimately rest on this assumption, should it come to that point. True, sometimes people say a bad reason is "no reason at all." But we understand this to mean that it is not a good reason, just as we might respond to a bad argument by saying "that's not an argument," or characterize a mediocre fastball as "no fastball at all," or say that a defective knife is "not a knife."12 There are bad reasons, just as there are bad arguments, mediocre fastballs, and defective knives. ${ }^{13}$

12 Recall this memorable scene from the movie Crocodile Dundee (1986). Brandishing a switchblade, a mugger threatens Sue Charlton and Crocodile Dundee. Sue says to Dundee, "Give him your wallet." Dundee asks, "What for?" Sue responds, "He's got a knife," whereupon Dundee chuckles, "That's not a knife," draws a giant Bowie knife and says, "That's a knife."

${ }^{13}$ Even my opponents agree, e.g. Dancy 2000: 3. 


\section{Applications}

This section explains two ways an ontological theory of reasons could affect debates in normative epistemology.

\section{A. Mentalism}

According to Earl Conee and Richard Feldman, we best understand epistemological internalism as a commitment to this core principle: no contingent non-mental factor can help determine whether you are epistemically justified in holding any doxastic attitude (Conee and Feldman 2001: 57 - 8). They advocate this principle and call their view "mentalism."

Unquestionably your reason for believing something helps determine whether your belief is epistemically justified. Now suppose for the sake of argument that factualism is the correct theory of reasons and that Conee and Feldman are correct about internalism. But then it follows that internalism is false. For my belief that, say, a school bus is parked at the corner is based on the indisputably contingent non-mental fact that a school bus is parked at the corner, rendering my belief's justification dependent on a contingent non-mental fact.

Approaching the matter from a slightly different direction, consider what a factualist would say about Moore's belief that he has two hands. What reason does Moore have that propositionally justifies $<$ I have two hands $>$ for him? (I use angle brackets to name propositions.) In other words, what reason does Moore have that 
makes belief the epistemically appropriate attitude for him to take toward $<$ I have two hands $>$ ? Depending on which version of factualism we consider, it might be the fact that he has two hands, or the state of affairs consisting of him having two hands, or even his hands themselves. On any of these versions, Moore's reason is nonmental and contingent. It is a "plainly external factor" that partly determines which doxastic attitude is justified for Moore.

If factualism is true, then mentalism is false.

\section{B. BonJour's Objection}

Laurence BonJour objects to externalism about epistemic justification because it supposedly entails that a person's reasons can be "outside his cognitive grasp" or "cognitively unavailable" to him (BonJour 2003: 24 - 7). But BonJour's objection appears compelling only if we fail to adequately distinguish the debates between internalists and externalists on the one hand, and statists and factualists on the other. (A word of caution: BonJour's (2002: 223) view of the internalism/externalism dispute in epistemology differs markedly from Conee and Feldman's, so you shouldn't expect my discussion in this subsection to cohere seamlessly with the previous subsection's claims or implications about the nature of internalism.)

BonJour attempts to elicit the relevant anti-externalist intuition through a vivid description of externalism's purported essence.

The internalist idea [is] that the justifying reason for 
[any belief] ... must somehow be cognitively available to the believer himself, within his cognitive grasp or ken. At first glance, the credentials of this idea seem quite clear and straightforward: If the belief is to be justified for that particular person (rather than perhaps for someone else), then it seems at least initially obvious that the reason for thinking it to be true must be one to which that person himself has access. (BonJour 2003: 24 - 25; see also BonJour 2002: 222)

"It is this internalist requirement that the justifying reason be cognitively available," BonJour explains, "that externalist views propose to discard." The externalist's basic idea: there are "special sorts of reasons" that justify belief despite being "cognitively unavailable to the person."

Externalists who are also statists (call them e-statists) can simply grant "the internalist idea" that all your reasons are readily available to you, because on their view reasons are nothing but your very own mental states. ${ }^{14}$ The counterintuitiveness of externalism, as BonJour describes it, derives partly from illegitimately wedding it to factualism. ${ }^{15}$ Of course no inaccessible fact could be your reason for believing, because no fact plays that role-mental states do.

\footnotetext{
${ }^{14}$ This also might need to involve some restriction on which mental states can be reasons. I won't pursue the details here.

15 Traces of this can be detected in some of BonJour's earliest writings on the subject. See BonJour 1978: 266 - 269 [Sections III - IV], where he criticizes Armstrong's externalist theory of knowledge, and also BonJour 1992: 134 - 135.
} 
E-statists of course accept that external facts sometimes help determine the quality of your reason, i.e. whether your reasons are good or bad. Some of these facts may well be "unavailable" to you at the time (e.g. whether your color vision is reliable in certain conditions). But that doesn't commit them to saying that those "unavailable" facts count as your reasons for believing. Not everything relevant to your belief's epistemic quality gets counted as one of your reasons for holding the belief. ${ }^{16}$

\begin{abstract}
We now shift to the paper's main arguments. I first address an influential argument against psychologism (section 3). Then I argue against abstractionism and factualism, the two most influential versions of anti-psychologism (sections 4 and 5). Next I present an argument for statism, the version of psychologism I advocate (section 6). Finally I respond to four common concerns (section 7).
\end{abstract}

\title{
3. Psychologism Refuted? ${ }^{17}$
}

Many authors distinguish between motivating and normative reas-

${ }^{16}$ Huemer (2007: 42 - 8) appears to make a related mistake (ironically, in arguing against BonJour, among others), but in another context (2009: 227) goes some way toward dispelling the appearance.

${ }_{17}$ Minor terminological note: In what follows, for convenience I often use 'normative' rather than 'normative or evaluative', understanding the normative broadly to include the evaluative. Some prefer to reserve 'normative' for deontological matters (e.g. requirements and permissions), and 'evaluative' for axiological matters (e.g. good and bad). 
ons (e.g. Smith 1994). Insofar as this suggests that motivating reasons are not also normative, it is a serious mistake (Dancy 2000). When it comes to epistemic reasons, there are not two sorts of reasons, but rather one sort of thing that plays two roles. Many of our beliefs are based on reasons, and intuitively many of those reasons -the very same ones that motivate our beliefs-are good. So an acceptable theory of reasons should respect their normative role.

Some believe this spells doom for psychologism. Consider the following argument suggested by Jonathan Dancy's discussion of psychologism (Dancy 2000: 102 - 8; see also Miller 2008: 233).

D1. If psychologism is true, then it is impossible to believe for a good reason..$^{18}$ (Premise)

D2. But it is possible to believe for a good reason.

18 Dancy (2000) discusses "the three-part story," which proponents of psychologism allegedly will tell when trying to reconcile the motivational and normative dimensions of reasons understood as psychological items. The "normative constraint" states that motivating reasons must be capable of being good reasons. In Dancy's words, the normative constraint "requires that a motivating reason ... be the sort of thing that is capable of being among the reasons in favor of so acting; it must, in this sense, be possible to act for a good reason," (p. 103). Dancy then says, "The three-part story fails the normative constraint in a very blatant way, for it renders us more or less incapable of doing an action for any of the reasons that make it right. It makes it impossible, that is, for the reasons why we act to be among the reasons in favor of acting," (p. 103). Later Dancy extends this thought to epistemic reasons: "I have been trying to show that the three-part story is committed to the paradoxical claim that it is impossible to do an action for the reason that makes it right. As I put it earlier, the reasons why we act can never be among the reasons in favor of acting if the three-part story is true. This paradox is even more marked in the theory of theoretical reasons (reasons for belief) than in the theory of practical reasons," (p. 105, emphasis added). 
(Premise)

D3. Therefore psychologism is not true. (From D1 and D2)

Skeptics might deny D2, but I won't. The culprit is D1. Psychologism is consistent with a wide variety of views about what makes reasons good.

Suppose for the sake of argument that reasons are mental states. And suppose that simple reliabilism provides a sufficient condition for good reasons: if your mental state $\mathrm{M}$ reliably indicates that $\mathrm{Q}$, then $\mathrm{M}$ is a good reason for you to believe Q. I am presently undergoing an experience as of a rectangular surface, which experience reliably indicates the presence of a rectangular surface before me. Based on that experience, I believe that a rectangular surface lies before me, and consequently believe for a good reason.

Or suppose that reliability does not suffice for good reasons: you must also be aware that $\mathrm{M}$ reliably indicates that $\mathrm{Q}$. This further condition presents no great difficulty. We can simply add to the description of the case that I am aware that my visual experience reliably indicates that a rectangular surface lies before me.

Or to take a more unorthodox suggestion, suppose that divine command epistemology is correct: $\mathrm{M}$ is a good reason for you to believe Q if and only if God wills you to believe Q based on M. I presently have an intuition that the existence of unnecessary evil precludes God's existence. God wills that I endorse the content of that intuition. I do so and consequently believe for a good reason.

We could multiply examples but the basic point is already clear. 
Psychologism does not rule out believing for a good reason. But then why do some people find D1 plausible?

The mistake derives from conflating "normative reasons" (or "normative states of affairs") with "good reasons." Consider for example how Dancy describes reasons' normative dimension:

[The normative dimension] requires that a motivating reason ... be the sort of thing that is capable of being among the reasons in favor of so [believing]; it must, in this sense, be possible to [believe] for a good reason. (Dancy 2000: 103) $)^{19}$

But a good reason needn't comprise all the factors contributing to its goodness. Consider again our simple reliabilist theory of good reasons. My visual experience is a reliable indication, and hence good reason for me to believe, that a rectangular surface lies before me. Much besides my psychology helps make the experience reliable, including natural laws connecting the ambient conditions, the surface's reflectance properties, and my visual system's output. Or consider again divine command epistemology. God's will makes my intuition a good reason, but obviously my intuition does not include God's will.

Dancy and others think that anti-psychologism holds an advantage because it respects the idea "that good reasons can be, or be grounded in, considerations other than those concerning the psy-

19 See the previous note for an explanation of the bracketed material. Miller 2008: 234 also slides from "normative reasons" to "good reasons." 
chology of the agent," in particular "features of our surroundings" (Dancy 2000: 137). But their view enjoys no such advantage. Psychologism's proponents can fully and consistently endorse the claim that non-psychological features of our surroundings contribute to a reason's quality.

We should note an important similarity between Dancy's and BonJour's discussions. BonJour's discussion might easily lead us to mistake statism's virtues for internalism's virtues. Similarly Dancy's discussion might easily lead us to mistake externalism's virtues for factualism's virtues.

\section{Two Problems for Abstractionism}

This section presents two problems for abstractionism. But let me first say something about what motivates abstractionism.

Abstractionism is attractive, I think, partly because it complements the view that evidential relations are founded in logical relations among propositions. If you thought that reasons were propositions, and you thought, as at least some leading epistemologists do, ${ }^{20}$ that logical relations determine evidential relations, then your ontological theory of reasons would cohere nicely with your theory of evidence. Our beliefs would be based on the very same things en-

${ }^{20}$ Here I think of Fumerton (1995), who endorses a logical theory of probability as the only plausible response to skepticism, and BonJour (2003), who likewise endorses inference to the best explanation as the only plausible response. See also Chisholm 1989: 52 and Feldman 1995. 
tering into evidential relations with one another. Whether or not this motivation ultimately withstands scrutiny, ${ }^{21}$ I can see how such a combination might initially seem attractive

\section{A. The Problem of Circularity ${ }^{22}$}

Suppose I undergo a perceptual experience with the content $<$ here's a rectangular surface $>$, whereupon I come to believe $<$ here's a rectangular surface $>$. This seems like a perfectly good way to come to know that there's a rectangular surface before me.

According to abstractionism, in such a case my reason for believing the proposition <here's a rectangular surface $>$ is the proposition <here's a rectangular surface $>{ }^{23}$ But this means that in heeding the call of perceptual experience, I am moving in a circle. For if $<\mathrm{Q}>$ is among your reasons for believing $\mathrm{Q}$, then you are thereby moving in a circle. This opens up abstractionism to the charge that it invites skepticism about perceptual justification and knowledge.

But even if we reconcile ourselves to the idea that moving in a circle could enhance justification and yield knowledge, we still ought to reject abstractionism because it entails that to heed the call

${ }^{21}$ Harman 1986 persuasively criticizes the idea that we can read off epistemic norms from logical relations among propositions.

${ }^{22}$ A referee suggested to me that they'd seen a version of this problem before. I myself do not recall seeing it discussed. In any event, I trust that the ensuing set of objections, responses, replies, etc. helps advance the discussion.

${ }^{23}$ Strictly speaking I should say, "the proposition <here's a rectangular surface> is among my reasons for believing <here's a rectangular surface>." This complication makes no difference to my argument, and could be stipulated away if necessary, so I set it aside. 
of experience is to move in a circle. Not a hint of circularity infects such a transition. ${ }^{24}$

Let me precisely state this argument, using the phrase 'to heed the call of experience' to neutrally express what I would otherwise state by saying 'to believe $\mathrm{Q}$ directly on the basis of an experience as of Q'.

1. If abstractionism is true, then to heed the call of experience is to believe $\mathrm{Q}$ directly on the basis of $\mathrm{Q}$ itself. (Premise)

2. To believe $\mathrm{Q}$ directly on the basis of $\mathrm{Q}$ itself is to move in a circle. (Premise)

3. Therefore if abstractionism is true, then to heed the call of experience is to move in a circle. (From 1 and 2)

4. But it is not the case that to heed the call of experience is to move in a circle. (Premise)

5. Therefore abstractionism is not true. (From 3 and 4)

The argument is valid so abstractionists will want to reject one or more premises. ${ }^{25}$

24 Thanks to Eugene Mills for conversation on this point.

${ }^{25}$ If the logic of 'to $A$ is to $B$ ' is not clear enough, we can recast the argument using conditionals instead.

1. If abstractionism is true, then if $S$ heeds the call of experience, then $S$ thereby believes $Q$ directly on the basis of $Q$ itself. (Premise)

2. If $S$ (thereby) believes $Q$ directly on the basis of $Q$ itself, then $S$ thereby moves in a circle. (Premise)

3. Therefore if abstractionism is true, then if $S$ heeds the call of experience, then $S$ thereby moves in a circle. (From 1 and 2)

4. It is not the case that if $S$ heeds the call of experience, then $S$ thereby moves in a circle. (Premise) 
Some might deny 1 on the grounds that perceptual content is nonpropositional. If it is non-propositional, then it does not feature $\langle\mathrm{Q}\rangle$, so there's no danger of circularity. But many abstractionists will want to avoid this route (e.g. Brewer 2005). And regardless whether perceptual experience is non-propositional, the same problem arises in cases where you believe $\mathrm{Q}$ upon intuiting $\mathrm{Q}$, because the intuition features $\langle\mathrm{Q}>$. No one disputes that intuitions have propositional content. ${ }^{26}$ But again, to endorse the content of an intuition is not to move in a circle.

Others might deny 1 on the grounds that nothing in the precipitating experience's content exactly matches the perceptual belief's content. You could implement this strategy by arguing that we have only a single generic propositional attitude, and treating 'intuition' in 'an intuition that Q' as part of the content. Likewise for 'belief' in 'a belief that Q', 'hope' in 'a hope that Q', and 'perception' in 'a perception that Q', etc. Thus rather than having different kinds of attitude with the same content, we get a single type of attitude with differently "colored" content, yielding a content mismatch:the attitude that belief- $Q$ would be based on the content $<$ intuition-Q $>$ or $<$ perception-Q>. Clever as it is, this drastic response forces us to relinquish the many distinct propositional attitudes featured in folk psychology, which we should avoid if possible. And it is also implaus-

5. Therefore abstractionism is not true. (From 3 and 4)

${ }^{26}$ BonJour (2001: 677; 2005: 100) claims that the most fundamental intuitions must have non-propositional content. But many retail intuitions undoubtedly have propositional content, which suffices for my purpose. 
ible to lump perception in with the propositional attitudes, as the proposal envisions (Millar 1991: Chapter 1). ${ }^{27}$

Alternatively abstractionists could deny 2. But given 2's intuitive credentials, this will not be easy. Here abstractionists find help from Roy Sorensen (1991), who denies a closely related principle concerning arguments.

Sorensen argues that at least some arguments of the form ' $Q$, therefore Q' are not circular. Consider these examples, inspired by Sorensen's:

(A) Some arguments contain their conclusion as a premise. Some arguments contain their conclusion as a premise.

(B) Some sentences contain fewer than seventy-two words. Some sentences contain fewer than seventy-two words.

(C) You have considered at least one argument. You have considered at least one argument.

Sorensen reasons as follows. Each of A - C is rationally persuasive.

27 Another move in logical space, available to abstractionists at this point, is less plausible but perhaps worth mentioning. Abstractionists could accept that perceptual experience has propositional content and accept that the typical perceptual belief that $Q$ is precipitated by a perceptual experience as of $Q$, but nevertheless insist that the belief is based on some other aspect of the precipitating experiences's content. Propositional content does not exhaust perceptual content-intuitively, there is also raw sensory content-and a typical experience will present more than one proposition as true. So for example suppose I believe <here's a rectangle>, precipitated by a perceptual experience with the content <here's a rectangle> and also with the content <here's something>. On the view under consideration, my belief that here's a rectangle might be based on <here's something> rather than <here's a rectangle>, thus avoiding circularity. As I said, this is a possible view, but what motivation is there for it? 
Yet each contains the conclusion as a premise. And "no rationally persuasive argument is circular." Therefore A - C are noncircular (Sorensen 1991: 248).

We might extend Sorensen's reasoning to cover the mental transition from a perceptual experience or intuition that $\mathrm{Q}$ to the belief that Q. Having a perceptual experience (or intuition) that $\mathrm{Q}$ rationally persuades us to believe that $\mathrm{Q}$. But moving in a circle never rationally persuades. Therefore the transition from a perceptual experience (or intuition) that $\mathrm{Q}$ to a belief that $\mathrm{Q}$ does not constitute moving in a circle.

Sorensen's argument's weak link is the premise that no circular argument ever rationally persuades. Sorensen claims this is a necessary feature of circular arguments (Sorensen 1991: 248). But this seems false. An argument could be blatantly circular or subtly circular. A subtly and undetectedly circular argument might rationally persuade. People we know to be experts might even reassure us that the argument is not circular. In such a case the argument could rationally persuade us. (I wager that with some ingenuity we could create an actual situation like this in nearly any introductory logic course.) Circularity does not preclude rational persuasiveness.

\section{B. The Problem of Withholding}

I'll demonstrate this problem with a two-stage example.

First stage: Nevil withholds on the question whether there is 
unnecessary suffering in the world. ${ }^{28}$ He also believes that God exists only if it is false that there is unnecessary suffering in the world. The withholding and belief together prompt Nevil to withhold on whether God exists.

What are Nevil's reasons for withholding on whether God exists? Statists answer: his withholding on whether there is unnecessary suffering in the world, and his belief that God exists only if it is false that there is unnecessary suffering in the world. True to form, abstractionists answer that Nevil's reasons are the propositional contents of the mental states cited by the statist: the proposition $<$ God exists only if it is false that there is unnecessary suffering in the world $>$ and the proposition <there is unnecessary suffering in the world $>$. But this makes Nevil sound completely unreasonable: surely he ought to disbelieve that God exists based on those reasons! Yet Nevil isn't being unreasonable. Abstractionism seems to yield the wrong verdict here.

Second stage: Now Nevil gets hit on the head, which simultaneously knocks him unconscious and causes him to believe that there is unnecessary suffering in the world. (Note: Nevil does not think he has been hit on the head and reason from there to the conclusion that there is unnecessary suffering in the world; rather, the hit simply causes the belief through some non-rational process.) Upon waking, Nevil updates his other attitudes accordingly. Now he disbelieves that God exists.

\footnotetext{
${ }^{28}$ Where I use 'withholds' others may use 'suspends judgment' or 'reserves judgment'. These expressions are synonymous.
} 
What are his reasons for disbelieving that God exists? Statists answer: his belief that there is unnecessary suffering in the world, and his belief that God exists only if it is false that there is unnecessary suffering in the world. Now comes the peculiar part. Abstractionists again answer that Nevil's reasons are the proposition $<\mathrm{God}$ exists only if it is false that there is unnecessary suffering in the world > and the proposition <there is unnecessary suffering in the world $>$. In other words, on their view Nevil (in the second stage) disbelieves that God exists for the exact same reasons he previously (in the first stage) withheld on whether God exists. This result is extremely counterintuitive.

In response abstractionists might deny that withholding is a genuine propositional attitude and replace it with special beliefs. So instead of withholding on <there is unnecessary suffering in the world $>$ in the first stage, Nevil believes the proposition <it's unclear whether there is unnecessary suffering in the world $>$. This response might handle the example, but at a steep cost: it is implausible on phenomenological grounds and it contradicts a broad consensus in epistemology that withholding is a genuine propositional attitude, one that you are at times required to take toward a proposition (e.g. Chisholm 1989, Feldman and Conee 1985, Sosa 1991).

Alternatively abstractionists might look for propositions "in the neighborhood" of the originals to serve as Nevil's reasons. For instance they might say his reasons are propositions about his mental states. ${ }^{29}$ So in the first stage Nevil's reasons are $<$ I believe that God

${ }^{29}$ Some will rightly wonder whether this violates the spirit of anti-psy- 
exists only if it is false that unnecessary suffering exists in the world $>$ and $<$ I withhold on whether unnecessary suffering exists in the world $>$, while in the second stage they are $<$ I believe that God exists only if it is false that unnecessary suffering exists in the world $>$ and $<$ I believe that unnecessary suffering exists in the world $>$.

But this response fails to address the underlying problem. To see why, notice we can stipulate that Nevil lacks the conceptual resources to entertain the proposition $<$ I withhold on whether unnecessary suffering exists in the world $>$ because he lacks the concept WITHHOLDING. And if he cannot entertain that proposition, then it obviously cannot be his reason for holding any doxastic attitude.

\section{Two Problems for Factualism}

This section presents two problems for factualism. But first I will discuss the motivation for factualism.

Suppose you ask Dick what his reason is for believing that Iraq poses a threat to the United States. It would be perfectly natural for Dick to respond, "The fact that the intelligence reports say that Iraq possesses nuclear weapons." Similarly in response to the question 'What's your reason for thinking you have hands?' one natural response would be 'The fact that I do'. Factualists take such talk at face value and build a theory of reasons that reflects it, claiming ordinary usage as a motivation for their view. But factualists tread on chologism. I won't pursue the matter here. 
dangerous ground here. Unreflective ordinary usage clearly favors dualism. We cite as reasons psychological items too. If asked what my reason is for thinking that this is the right person for the job, a natural response would be 'My conviction that she is trustworthy'.

Factualism also enables a simple, distinctive response to certain forms of skepticism. Factualism says our reasons reach all the way out into the non-mental world, and our beliefs are based on the facts themselves rather than some mental item that could have been in place even had the facts been radically different. Factualism thus provides for a kind of infallibilism. If your belief that there's a lectern in front of you is based on the fact that there's a lectern in front of you, then given its basis, your belief couldn't have been false. But of course psychologism itself does not rule out this type basis-relative infallibilism. If combined with a strong version of externalism about mental content or mental states, psychologism could likewise provide basis-relative infallibility.

\section{A. The Evil Demon Problem}

The evil demon problem derives from the previously mentioned intuition that you and your victimized twin each believe $<$ I'm reading an epistemology paper $>$ for the same reasons. Factualism runs afoul of this intuition, for it is a fact that you're reading a paper, but it is not a fact that Vic is reading one. To state the argument precisely:

6. If factualism is true, then you and Vic do not believe for the same reasons. (Premise) 
7. You and Vic do believe for the same reasons. (Premise)

8. Therefore factualism is not true. (From 6,7 )

But don't factualists have an easy response? If reasons are mental facts, then 6 is false because for every mental fact about you, there is a matching fact about Vic (as stipulated in the case's description). This provides a straightforward sense in which you and Vic believe for the same reasons. Yet things are not so simple. Recall that factualism is the view that reasons are non-mental facts or states of affairs. Factualists cannot respond this way without abandoning their view. Indeed leading factualists explicitly reject it. They say that it and statism are "unite[d] in opposition" against their view (Dancy 2000: 122; see also Collins 1997). In light of the motivation for factualism, we can easily see why.

\section{B. The Problem of False Facts}

Sometimes "facts" are not really facts. Dick got the facts wrong. The intelligence reports didn't say, as Dick mistakenly believes, "Iraq does possess nuclear weapons," but rather, "Iraq does not possess nuclear weapons." Dick's belief cannot be based on the fact that the reports say, "Iraq does possess nuclear weapons," because no such fact exists.

Surely factualists don't want to say that Dick believes what he does for no reason, because that's obviously false. But then what can factualists say? (Cases of hallucination, where nothing even approximating the purported fact is around to do the relevant work, represent the most extreme version of this problem. But nothing so extra- 
vagant is needed to illustrate the point. I want to avoid the impression that the problem is endemic to extravagant cases, so I prefer an unremarkable case of false belief or perceptual error instead.)

One popular strategy is the appositional account, which states that reasons are facts as the subject understands them, or as they seem to the subject (Collins 1997: 120 - 1; Dancy 2000: 110 - 11, $132-5$ ). On this approach, Dick's reason for believing that Iraq poses a threat to the United States is the fact that the intelligence reports say that Iraq possesses nuclear weapons, as he understands things. Crucial to this strategy is the claim that the modifier 'as he understands things' is not, in Arthur Collins' words, "a shift to the mental realm." yet I'm unable to hear it as anything but that. In a word, it strikes me simply as a convoluted way of capitulating to psychologism. It is the subject's understanding of the facts that prompts belief.

Why not just settle for the flat-footed response, according to which Dick's reason for believing that Iraq poses a threat to the United States is the fact that the intelligence reports said that Iraq does not possess nuclear weapons? Because this cure is worse than the disease. It makes Dick look flat-out irrational, perhaps incomprehensible. (We could of course build up the case so that Dick knew the following conditional: Iraq possesses nuclear weapons aimed at the United States if and only if the intelligence report says that Iraq does not possess nuclear weapons. Perhaps he has excellent evidence to suspect that the intelligence community will try to deceive him on this matter. Nothing of the sort is true in the present case.) Sometimes belief prompted by perceptual error is perfectly reasonable. Much 
better would be to say that Dick's reason is his perceptual experience as of the intelligence report saying so-and-so.

\section{Collins' Argument}

Before moving on, I'd like to address an argument due to Arthur Collins (1997: esp. $112-14,117-18$ ). Collins focuses on reasons for action rather than belief, but his discussion challenges statism across the board.

Collins's argument is subtle and sometimes elusive but it appears to come down to this. Suppose someone asks you why you believe the ferry is your only option for crossing the river. You sincerely respond, "I believe it because the bridge is closed." This is the factualist explanation: you cite a fact as your reason. In offering it you express your belief that the bridge is closed. But suppose you had instead responded, "I believe it because I believe that the bridge is closed." This is the statist explanation: you cite a mental state as your reason. You must believe the bridge is closed if this explanation is correct, so in offering it you express your belief that the bridge is closed. The statist explanation commits you to everything the factualist one does, in effect merely re-expressing the factualist explanation in different words. We might put the point this way: the statist explanation is just the factualist explanation in disguise..$^{30}$

30 Two crucial passages from Collins 1997:

In other words, in the context of reason-giving explanation, the restatement that moves from ' . . . because the bridge is closed', to '. . . because I believe that the bridge is closed', does not delete the claim about the 
The argument commits a mistake. From the fact that the statist explanation is correct only if you believe the bridge is closed, it does not follow that in offering it you express your belief that the bridge is closed. Consider a similar case. You ask Randy why he's leaving the country and he calmly replies, "I'm leaving the country because I'm enraged at my father." His explanation is correct only if he is in fact enraged at his father. Yet he does not express his rage by offering the explanation. We have no reason to treat your explanation differently from Randy's in this respect.

\section{An Argument For Statism}

Having demonstrated the competition's major weaknesses, I will now present what I consider the best argument for statism.

bridge. It makes that claim, and it adds the qualifying admission that making it may be making a mistake. The claim made in the explanation is a claim about an objective circumstance. [Your] restatement is not a psychologising restatement. [You do] not delete the claim about the objective circumstance made in the unrestated form. If [you] deleted that claim [you] would drop the explanation that [you] first gave. (113-114)

[T]he explanation proffered by '[...] because I believe that $p$ ' absolutely depends on the fact that these words do express the speaker's commitment to the truth of $p$. The explanation makes the claim about the objective circumstance and cannot delete that claim. No formula that the speaker could substitute that actually deletes this commitment in favor of some other subject matter, such as the existence or character of an inner reality in the speaker, can convey the right explanation. (118) 
When you believe $\mathrm{Q}$ for a reason, the reason explains your belief. Identifying your reason allows us to understand your cognitive performance. We seek this explanation by reasons-what I'll call a reasons-explanation-when we ask, "What's your reason for believing that?" or "Why does she think that?" Understanding is the first step toward evaluating. Of course, understanding might reveal that you performed poorly.

Having the relevant mental states in place is necessary for us to understand your reasons. Statism's opponents say that reasons are propositions, or facts, or objects, or states of affairs, etc. For it to be even remotely plausible that any such thing is your reason for believing $p$, some mental state of yours must take it as an object or depict it. If I report that Jeb believes he will win the election because he's ahead in the polls, but Jeb isn't even aware that he's ahead in the polls, then my report is obviously false. ${ }^{31}$

Having the relevant mental states in place and appropriately related is sufficient for us to understand your reasons. To understand a person's reasons, all we need is for his mental states-in most cases some very small portion of them-and the relations among them to be displayed. Consider Barry. Barry has an ordinary visual experience as of a bear in his yard, which in conjunction with his habit of taking experience at face value causes him to believe that there's a bear out there. That description allows you to understand Barry's reason.

${ }^{31}$ Even statism's opponents concede this. See Scanlon 1999: 56, Collins 1997: 121, and Kim 1998: 78. 
Putting those two things together, having the relevant mental states in place and appropriately related is both necessary and sufficient for us to understand your reasons.

Statism best explains the striking fact expressed by that biconditional. If your reasons just are your mental states, then obviously having the relevant mental states in place and related in the right way is both necessary and sufficient for a reasons-explanation. By contrast statism's competitors claim that some other items are your reasons. But it is superfluous to introduce further items into the reasons-explanation, given that the mental states are themselves both necessary and sufficient.

Therefore, by inference to the best explanation, statism is true. Call this the master argument for statism.

\section{Response to Common Concerns}

This section responds to four common concerns about statism.

\section{A. Enablers}

I encounter a common challenge to the explanatory relevance of the subject's mental states. ${ }^{32}$ The challenge begins by distinguishing items that really do the explanatory work (the explanans) from

32 James Dreier put the objection to me in conversation. Dancy (2000: $127-128$ ) also presents a version of it, though he expresses only minimal confidence in its prospects. Hookway 2006 employs the reason/enabler distinction, but in a different way. 
mere background or enabling conditions. This distinction is motivated independently of the present discussion. Take one of Tiger Woods's clutch putts. His skill and execution explain why the ball falls into the cup. Of course the ball would not have fallen into the cup had Earth's gravity weakened significantly, but (the strength of) Earth's gravity merely forms part of the background conditions enabling Woods to sink the putt through skill and execution. The challenge continues by speculating that the subject's mental states merely enable the real reason-be it a proposition or some nonmental fact-to explain the subject's belief.

We might respond by rejecting the distinction between explanans and enabling conditions, on the grounds that any attempt at sorting factors into the two categories will involve "capricious" or "invidious" discrimination. ${ }^{33}$ But I will not respond that way. Instead I will grant the distinction's viability and ask whether the subject's mental states behave like enabling conditions in reasons-explanations. Reflecting on our explanatory practices reveals that they do not. (Before proceeding, it merits emphasis that my opponents have done no more than speculate that the subject's mental states are enabling conditions. No evidence or argument for this claim is yet forthcoming.)

Consider the following conversation:

\section{Conversation 1}

${ }^{33}$ See Mill 1846: 198 and Lewis 1986: 162. Their speak of an analogous distinction for causation (background conditions versus causes proper), whereas we focus on the more general notion of explanation. 
A: Why were all Belle's belongings destroyed?

B: Because a fire broke out in her apartment.

A: Why was there oxygen in her apartment?

Oxygen's presence is a paradigm case of an enabling condition. ${ }^{34} \mathrm{~A}$ 's second question would seem odd in any normal context. Had A wanted to better understand why Belle's belongings were destroyed, we might have expected him to ask, "Why was there a fire in her apartment?"

Consider also:

\section{Conversation 2}

A: Why did the vase break?

B: Because it fell from the window.

A: Why was there a window?

Again the window's presence is an enabling condition. And again A's second question would sound strange in any normal context because he's inquiring directly after an enabling condition. One would have expected a question such as, "Why did it fall?"

Now consider this exchange:

\section{Conversation 3}

A: Why do you believe that Woods will sink the putt?

B: Because (of the fact that) Woods excels at putting.

A: Why do you believe that he excels at putting?

Here A's second question sounds perfectly natural (and this despite

${ }^{34}$ Hart and Honore 1985. 
B's answer being entirely favorable to anti-psychologism). This distinguishes B's belief from the enabling conditions mentioned in the previous conversations.

One might object that A's second question in Conversation 3 sounds natural because B asserts that Woods excels at putting, thereby expressing her belief that Woods excels at putting, thereby making her belief fair conversational game. A detects this and questions B accordingly. This objection misfires because we can construct a similar example without B expressing a belief at all.

\section{Conversation 4}

A [to C]: Why does B believe that Woods will sink the putt?

C: Because (of the fact that) Woods excels at putting.

A [walks across the hallway to confront B]: Why do you believe that Woods excels at putting?

A's second question again sounds perfectly natural.

Maybe it's not always odd to inquire directly about an enabling condition. It might be perfectly appropriate in certain contexts. But that is beside the point. Normally it is odd. The subject's mental states do not behave like enabling conditions. ${ }^{35}$ To encapsulate my re-

${ }^{35}$ One might worry, as did an anonymous referee, that my discussion presupposes a theoretical account of the explanans/enabler distinction that my opponents will reject. I have three responses to this worry. First, my opponents have not indicated that they favor or disfavor any particular theoretical account of the distinction-see, e.g., Dancy 2000: 127-so this worry is somewhat speculative. Second, to fully insure against the presupposition, I could make a weaker point and still advance the dialectic. My examples feature paradigm cases of enabling conditions. The subject's mental states are certainly unlike paradigm cases of enabling conditions, and any ad- 
sponse:

9. If the subject's mental states were mere enabling conditions, then normally it would be odd to inquire directly after them. (Premise)

10. But it is not normally odd to inquire directly after them. (Premise)

11. Therefore the subject's mental states are not mere enabling conditions. (From 9 and 10)

\section{B. Twins}

Intuitively you and your victimized twin believe what you do for the same reasons. Earlier I marshaled this intuition in favor of statism. But if reasons are mental states, then you and your twin don't have the same reasons after all: your mental states belong to you, and Vic's to Vic. Hence this intuition ironically work against statism.

The objection confuses numerical and qualitative senses of 'the same'. When each of two people owns a Volkswagen Beetle, we say they own "the same car," but this obviously means that they own qualitative similar cars-i.e. cars of the same kind-not numerically

equate theory of the distinction should respect this verdict. This does not rule out that they form a marginal class of enablers. But there is no quick route to my opponents' goals here, and they will need to present an account of the explanans/enabler distinction to convince us that mental states do form a marginal class of enablers. Third, grant for the sake of argument that all the points I make here presuppose an account of the distinction that my opponents will reject. That in itself does not evince any defect. If my response would tend to persuade a neutral third-party that mental states are not mere enablers, then I shall count it a success. 
one and the same car. Likewise your reasons are not numerically one and the same as your twin's, but they are exactly similar. You have a perceptual experience as of Q, which is your reason for believing $p$; Vic has a perceptual experience as of $\mathrm{Q}$, which is Vic's reason for believing $\mathrm{Q}$. You both have the same reason: a perceptual experience as of $\mathrm{Q}$.

\section{Sharing}

It's a truism that we often share our reasons with one another. Can statism do justice to this?

Yes. We can and often do share our thoughts and experiences with one another. You ask me what it was like growing up in Detroit in the 1980s, and I share some of my experiences with you. I ask you whether the Democrats will regain at least one house of Congress in 2006, and you share some of your hopes and expectations with me. We share our mental states with one another by expressing or depicting them.

\section{First-person Perspective}

When deliberating with an eye toward reaching a conclusion, we focus on outward facts and objects but not on our mental states (except in special cases). ${ }^{36}$ When adducing his reasons for believing that there are external objects, Moore focused on his hands, not his beliefs about his hands. He said, "Here is one hand, and here is an-

36 Collins 1997 and Kim 1998. 
other." ${ }^{37}$ He didn't say, "Here is one belief that here's a hand, and here is another." Surely some deference is due to the phenomenology of deliberation. But can statists do justice to it?

Yes, by citing the mental states that constitute (the relevant aspects of) the subject's first-person perspective. When Moore says, "Here is one hand, and here is another," he expresses two conscious occurrent beliefs, which partly constitute his perspective. In uttering those words, he communicates his perspective to us. He expresses his reasons to us. And of course he expresses his beliefs, not his hands..$^{38}$

Moore 1962: 24.

${ }^{38}$ For helpful conversations and feedback, I thank: Jonathan Dancy, James Dreier, Mylan Engel, Derek Ettinger, Ben Fiedor, John Greco, Stephen Grimm, Allan Hazlett, Jonathan Ichikawa, Ben Jarvis, Christopher Kane, Peter Klein, Clayton Littlejohn, John McDowell, Eugene Mills, Alastair Norcross, Bruce Russell, Mark Schroeder (twice?), Ernest Sosa, Matthias Steup, James Van Cleve, and two anonymous referees. Thanks also to audiences at the Brown Philosophy Graduate Forum in December 2005 and the Russell II Conference in March 2006. 


\section{References}

Alston, William P. 2005. Beyond "Justification": Dimensions of Epistemic Evaluation. Ithaca: Cornell University Press.

Alvarez, Maria. 2005. "Agents, Actions, and Reasons." Philosophical Books, vol. 46, no. 1, pp. $45-58$.

Bergmann, Michael. 2007. "Is Klein an Infinitist about Doxastic Justification?” Philosophical Studies, vol. 134, no. 1 (May 2007), pp. $19-24$.

Berkeley, George. 1710. A Treatise Concerning the Principles of Human Knowledge.

BonJour, Laurence. 1978. "Can Empirical Knowledge Have a Foundation?” American Philosophical Quarterly, vol. 15, no. 1, pp. 1 - 13. Reprinted in Sosa \& Kim, eds. . 1980. "Externalist Theories of Empirical Knowledge." Midwest Studies in Philosophy, vol. V, 1980, pp. 53 - 71. Reprinted in Crumley, ed.

. 1985. The Structure of Empirical Knowledge. Cambridge, MA: Harvard University Press.

. 1992. "Externalism/Internalism." In Dancy \& Sosa 1992.

. 2001. "Replies." Philosophy and Phenomenological Research, vol. 63, no. 3 (Nov. 2001), pp. $673-698$.

. 2002. Epistemology: Classical Problems and Contemporary Responses. New York: Rowman \& Littlefield.

. 2003. Epistemic Justification: Internalism vs. Externalism, Foundations vs. Virtues (with Ernest Sosa). Malden, MA: Blackwell. . 2005. "In Defense of the a Priori." In Steup \& Sosa, eds.

Brandom, Robert B. 2000. Articulating Reasons: An Introduction to Inferentialism. Cambridge, MA: Harvard University Press.

Bransen, J. \& S. E. Cuypers, eds. 1998. Human Action, Deliberation, and Causation. Dordrecht: Kluwer. 
Chisholm, Roderick. 1989. Theory of Knowledge, $3^{\text {rd }}$ eds. Englewood Cliffs, NJ: Prentice Hall.

Clark, Andy \& David Chalmers. 1998. "The Extended Mind." Analysis vol. 58, no. 1 (January 1998), pp. $7-19$.

Cohen, Stewart. 1998. "Contextualist Solutions to Epistemological Problems: Skepticism, Gettier, and the Lottery." Australasian Journal of Philosophy, vol. 76, no. 2, pp. 289-306. . 2005. "Contextualism Defended." In Steup and Sosa, eds.

Collins, Arthur. 1997. "The Psychological Reality of Reasons." Ratio, vol. 10, no. 2, pp. $108-123$.

Conee, Earl \& Richard Feldman. 2001. "Internalism Defended." American Philosophical Quarterly 38 (2001), pp. 1 - 18. Reprinted in Conee \& Feldman 2004. \& . 2004. Evidentialism: Essays in Epistemology. Oxford: Oxford University Press.

Crumley II, Jack S., ed. 1999. Readings in Epistemology. Mountain View, CA: Mayfield Publishing Co.

Dancy, Jonathan. 2000. Practical Reality. Oxford: Oxford University Press.

Darwall, Stephen. 1983. Impartial Reason. Ithaca: Cornell University Press.

Davidson, Donald. 1983. "A Coherence Theory of Truth and Knowledge.” Reprinted in Davidson 2001.

. 2001. Subjective, Intersubjective, Objective. Oxford: Clarendon Press.

DeRose, Keith. 1999. "Contextualism: An Explanation and Defense.” In Greco \& Sosa, eds.

DePaul, Michael \& Linda Zagzebski, eds. 2003. Intellectual Virtue: Perspectives from Ethics and Epistemology. Oxford: Oxford University Press.

Feldman, Richard. Feldman, Richard. 1995. "Authoritarian Epistemology.” Philosophical Topics, 23 (1995), 147 - 169. Re- 
printed in Conee \& Feldman 2004.

. 2002. Epistemology. Upper Saddle River, NJ: Prentice Hall.

Feldman, Richard \& Earl Conee. 1985. "Evidentialism.” Reprinted in Sosa \& Kim, eds.

Foley, Richard. 1990. "Skepticism and Rationality." In Sosa \& Kim, eds.

Fumerton, Richard. 1995. Metaepistemology and Skepticism. Lanham, MD: Rowman \& Littlefield.

Greco, John. 2003. "Knowledge as Credit for True Belief." In DePaul and Zagzebski, eds.

Greco, John \& Ernest Sosa, eds. The Blackwell Guide to Epistemology. Malden, MA: Blackwell.

Harman, Gilbert. 1986. Change in View. Cambridge, MA: MIT Press.

Hart, H. L. A \& A. M. Honore. 1985 [orig. 1959]. Causation in the Law. Oxford: Oxford University Press.

Hookway, Christopher. 2006. "Reasons for Belief, Reasoning, and Virtues.” Philosophical Studies, vol. 130, pp. 47- 70.

Huemer, Michael. 2007. "Compassionate Phenomenal Conservatism." Philosophy and Phenomenological Research, January 2007, pp. $30-55$.

. 2009. "Apology of a Modest Intuitionist." Philosophy and Phenomenological Research, January 2009, pp. $222-236$.

Kim, Jaegwon. 1998. "Reasons and the First Person." In Bransen \& Cuypers, eds.

Klein, Peter D. 1999. "Human Knowledge and the Infinite Regress of Reasons." Philosophical Perspectives, 13, Epistemology, 1999.

Lewis, David. 1986. "Causation.” Reprinted in Lewis 1987. . 1987. Philosophical Papers 2. Oxford: Oxford University Press. 
. 1996. "Elusive Knowledge." Australasian Journal of Philosophy, vol. 74, no. 4, pp. $549-67$.

McDowell, John. 1979. "Virtue and Reason." Reprinted in McDowell 1998.

. 1994. Mind and World. Cambridge, MA: Harvard University Press.

Mill, J. S. 1846. A System of Logic. New York: Harper \& Brothers.

Millar, Alan. 1991. Reasons and Experience. Oxford: Clarendon Press.

Miller, Christian. 2008. "Motivation in Agents." Noûs vol. 42, no. 2, pp. $222-266$.

Moore, G. E. 1962. "Proof of an External World." Reprinted in Sosa \& Kim, eds.

Neta, Ram. 2002. "S Knows That P." Noûs, vol. 36, no. 4, pp. 663 681.

. 2003. "Contextualism and the Problem of the External World." Philosophy and Phenomenological Research, vol. LXVI, no. 1, January 2003.

Nozick, Robert. 1981. Philosophical Explanations. Cambridge, MA: Harvard University Press.

Pryor, James. 2000. "The Skeptic and the Dogmatist." Noûs, vol. 34 , no. 4 , pp. $517-549$.

. 2005. "There is Immediate Justification." In Steup \& Sosa, eds.

Rieber, Steven. 1998. "Skepticism and Contrastive Explanation." Noûs, vol. 32, no. 2, $189-204$.

Scanlon, Thomas. 1999. What We Owe to Each Other. Cambridge, MA: Belknap Press.

Schaffer, Jonathan. 2005. "Contrastive Causation." The Philosophical Review, vol. 114, no. 3 (July 2005), pp. 327 - 358.

Smith, Michael. 1994. The Moral Problem. Malden, MA: Blackwell.

Sorensen, Roy A. 1991. “P, Therefore, P' Without Circularity.” The 
Journal of Philosophy, vol. 88, no. 5 (May 1991), pp. 245 266.

Sosa, Ernest. 1991. Knowledge in Perspective. Cambridge: Cambridge University Press. . 2003. Epistemic Justification: Internalism vs. Externalism, Foundations vs. Virtues (with Laurence BonJour). Malden, MA: Blackwell.

Sosa, Ernest \& Jaegwon Kim, eds. 2000. Epistemology: An Anthology. Malden, MA: Blackwell .

Steup, Matthias \& Ernest Sosa, eds. 2005. Contemporary Debates in Epistemology. Malden, MA: Blackwell.

Stoutland, Fredrick. 1998. "The Real Reasons." In Bransen and Cuypers, eds. 